\title{
This is real
}

\section{H. Holden Thorp}

Editor-in-Chief, Science journals. hthorp@aaas.org; @hholdenthorp

Last week, we ran what is likely to be one of the most widely read Science news stories ever-an interview with Dr. Anthony Fauci, director of the U.S. National Institute of Allergy and Infectious Diseases (NIAID). Fauci was strikingly candid about his desire for extraordinary measures to combat coronavirus disease 2019 (COVID-19), and he was unusually direct about the challenges in getting the administration to see how important it is for the country to maintain social distancing.

Despite the exceptional job they are doing providing factual updates during White House press conferences, Fauci and his accomplished colleague Dr. Deborah Birx have become targets for political attacks from allies of the administration who are not qualified health advisers and don't know what they are talking about. This is unacceptable. Facts about the spread of the virus and its dangerous health and societal consequences are not political. A survey of health officials shows this to be the case.

When I was chancellor of the University of North Carolina (UNC), I was fortunate to work closely with Dr. William Roper who was then dean of the UNC School of Medicine and the chief executive officer of UNC Health Care. Before we worked together, Bill had done separate stints running the U.S. Centers for Disease Control and Prevention (CDC) and the Centers for Medicare and Medicaid Services in the 1980s and early 1990s during Republican presidencies.

I tracked Bill down in North Carolina, where he is now interim president of the UNC system, to seek his thoughts about the coronavirus crisis and the response of the administration. "I would trust Tony Fauci with my life," he told me. Roper and Fauci worked closely together when Bill ran the CDC and Fauci was already the NIAID's director. Bill disagrees with statements by the current administration that minimize the importance of sustained social distancing. When I asked him when social distancing should end, he said we'll know it's time when the hospitals tell us that they are no longer overwhelmed. Or as Fauci said, "the virus makes the timeline."

Bill has always been measured in his statements about everything, but he became very exasperated when I asked about the international implications of this political fighting. He talked about a time in the past when the CDC director and Tony Fauci were treated like rock stars abroad, particularly in China, reflecting the respect for U.S. leadership in global health. The nationalism that now has flared up around the White House threatens to undermine the effort to manage a global crisis.

In looking at the papers coming to Science and posted on preprint servers, it is clear that the only way we can get a handle on the situation is with international collaboration. The data coming out of Chinese labs studying the virus-how it spreads and the disease that it causes-as well as the findings of Chinese scientists on the ground, are indispensable in finding a solution. That's why the racist labeling of the virus is doubly dangerous. In his interview with Science, when Fauci was asked if he would ever call it the "Chinese virus," he simply said, "No."

Bill Roper isn't the only former Republican health official sounding the alarm. Earlier this week, just as President Trump was shifting to messages about accelerating a return to work, his own former director of the Food and Drug Administration, Scott Gottlieb, struck a somber tone. Gottlieb has been an important and vocal advocate of prioritizing public health. He said in a Wall Street Journal op-ed on 22 March that "America's coronavirus epidemic is only beginning" and that "COVID-19 can't be allowed to rage through the country untamed."

Still, Fauci, Gottlieb, and Roper all believe that the United States can avoid the worst if it stays focused. Fauci has been pleading for a few more weeks of strong action and reminding people that the pandemic won't last forever. Roper is optimistic that students in the UNC system will return to classes in the fall. And Gottlieb ended his Wall Street Journal article by stating, "With the right mix of controlling transmission, expanding testing and deploying promising drugs, American ingenuity can beat back this pathogen."

But they're sober about the short term. I ended my conversation with Roper by asking what message he had for our readers. He was succinct: "This is real."

Published online 27 March 2020

10.1126/science.abb9223 